\title{
Entrepreneurship Education as a Way of Cultivating Entrepreneurial Thinking among Students of Malaysian Public Higher Learning Institutions
}

\author{
Armanurah Mohamad, Syahrina Abdullah, Awanis Ku Ishak, and Norashidah Hashim
}

\begin{abstract}
The aimed of this study were (1) to determine the level of entrepreneurial thinking and entrepreneurial thinking dimensions, namely, opportunity recognition, creative and innovative, ability to take risk and tolerance of ambiguity among Malaysian public higher learning institutions (PHLIs) students based on compulsory Basic Entrepreneurship (CBE) course taken; (2) to examine the significant differences of entrepreneurial thinking of PHLIs) students based on the CBE course taken; and (3) to examine the significant differences of all entrepreneurial thinking dimensions of PHLIs students based on the CBE course taken. This study used a quantitative approach. Descriptive statistics and t-test were used to analyze the data of the study. The sample consists of 1998 undergraduate students majoring in all fields of studies from twenty PHLIs in Malaysia. The findings showed that students taking CBE course have a moderately high level of entrepreneurial thinking, but in term of its dimension; opportunity recognition and risk taking have high level. As for creative and innovative, and tolerance of ambiguity demonstrated a moderately high level. The results showed significant differences of entrepreneurial thinking among PHLIs students based on the CBE course taken. Besides, this study found that there were significant differences of all entrepreneurial thinking dimensions among PHLIs students based on the CBE course taken. The implications of this study showed that in order to cultivate entrepreneurial thinking among students in all fields of studies, the PHLIs should take into consideration to include at least one Basic Entrepreneurship course as a compulsory subject for all students. This study also recommended that to increase the level of entrepreneurial thinking, and its dimension of creative and innovative, and tolerance of ambiguity, PHLIs should increase the entrepreneurship courses taken as compulsory subject.
\end{abstract}

Index Terms-Entrepreneurial thinking, entrepreneurship education, opportunity recognition, risk taking, tolerance of ambiguity, creative and innovative.

Manuscript received February 15, 2019; revised April 23, 2019. This work was supported by the Ministry of Higher Education Malaysia under Exploratory Research Grant Scheme (ERGS) SO CODE 12471.

Armanurah Mohamad and Norashidah Hashim are with the School of Business Management, Universiti Utara Malaysia, in Kedah Malaysia, Malaysia (e-mail: armanurah@uum.edu.my,norashidah@uum.edu.my).

Syahrina Abdullah and Awanis Ku Ishak are with the College of Arts and Sciences, Universiti Utara Malaysia, in Kedah Malaysia, Malaysia (e-mail: syahrina@uum.edu.my, awanis@uum.edu.my).

\section{INTRODUCTION}

Previous studies have shown that a country with numerous entrepreneurs is more advanced in its economy [1], [2]. Therefore, the development of potential entrepreneurs and entrepreneurs among students of higher learning institution (HLIs) need to be emphasized by HLIs. As reported by Buang et al. [2] and Ahmad et al. [3] majority of graduates do no interested to become entrepreneur, they prefer to be a job seeker than a job creator. This statement also supported the previous finding by Din et al. [4], Hussin et al. [5] and Ministry of Higher Education [6].

Findings from previous research has shown that among important basic key element to become entrepreneur is entrepreneurial thinking [7]. Hence, to produce entrepreneurs among graduates, HLIs students need to be cultivated with entrepreneurial thinking during their studies. Therefore this study attempt to answer the following questions:

1) What are levels of entrepreneurial thinking and entrepreneurial thinking dimensions, namely, opportunity recognition, creative and innovative, ability to take risk and tolerance of ambiguity among PHLIs students based on CBE course taken?

2) Is there a significant difference in entrepreneurial thinking among PHLIs students based on CBE course taken?

3) Is there a significant difference in entrepreneurial thinking dimension, namely, opportunity recognition, creative and innovative, ability to take risk and tolerance of ambiguity among PHLIs students based on CBE course taken?

This study showed that in order to cultivate entrepreneurial thinking among students in all fields of studies, the PHLIs should take into consideration to include at least one basic entrepreneurship course as a compulsory subject for all students. By cultivating entrepreneurial thinking among all PHLIs students will give chances for all students to explore and integrate their entrepreneurial thinking with their skills of expertise from their field of study at the university. This will give an opportunity for students to venture as student enterprise during their study or be graduate entrepreneurs as job creator after graduation. 


\section{LITERATURE REVIEW}

\section{A. Entrepreneurship Education}

Entrepreneurship is not inherited, but it characteristics can be cultivated and developed [1]-[2], [8], [9]. Therefore, entrepreneurship education and training play a very important role in developing new and potential entrepreneurs [7], [10].

Entrepreneurship education refers to education that emphasizes the aspect of creativity, innovation and the development of individual as entrepreneurs that include the aspects of cultivating entrepreneurial thinking and attitudes, as well as developing entrepreneurial skills among students [6]. Entrepreneurship education can developed students with a high level of thinking, attitude and inclination towards entrepreneurship [11]-[13]. It is also a process of acquiring knowledge and skills on all activities undertaken by entrepreneurs through formal or informal teaching and learning [14].

The purpose of entrepreneurship education is to build and develop students' potential towards a more creative, initiative and wise in making decision which can be molded through entrepreneurship curriculum and teaching and learning activities. Entrepreneurship education also educates an individual to identify opportunities and seize opportunities that emerge in the environment, translate the ideas into reality or economic activity, as well as become robust and sensitive to changes and uncertainty [15]. Meanwhile, Pyysiainen et al. [16] expressed that the main purpose of enterprise education is to develop entrepreneurial attitudes, skills, and enterprise attributes.

\section{B. Entrepreneurship Education in Higher Learning Institutions in Malaysia}

At HLIs in Malaysia entrepreneurship education is growing in academic and co-curricular. Efforts to integrate entrepreneurship education are carried out at higher education levels by the Ministry of Higher Learning, where the Division of Quality Assurance Learning has set the domain of entrepreneurship as one of the eight learning outcomes that students need to achieve at the end of a program offered by PHLIs [17]. To date, in most HLIs in Malaysia, there is an increase in entrepreneurship course offerings and entrepreneurship programs at undergraduate and postgraduate degrees [2], [7]. Various strategies are conducted through entrepreneurship education to produce graduates with entrepreneurial thinking, characteristics and attributes [18]. In addition, starting from the first semester of 2007/2008 Basic Entrepreneurship course is made as the core course at all PHLIs with the intention to inculcate entrepreneurship culture. Apart from the Ministry of Higher Learning, various other approaches are also used by HLIs in offering their entrepreneurship education [7]. The effort to create entrepreneurs in various fields is an important agenda to ensure that graduates do not depend just on jobs offer by employers after graduation [19]. In addition to the offering of entrepreneurship education in the form of academic curriculum, co-curricular activities are also implemented in HLIs in various forms such as through the involvement of clubs or associations in various entrepreneurial activities including hands-on business activities.

\section{Entrepreneurial Thinking}

Entrepreneurship is a way of thinking that are influenced by opportunities [20]. According to De Bono [21] to change the ideas into opportunities, it requires thought which involves time and effort to think. Moreover, the main purpose of thinking is to formulate the ideas of opportunity. Second, is the ability to assess the benefits of opportunity, and third, is to ensure the feasibility of opportunities. A similar concept is expressed by Hashim [22] where she stated that entrepreneurial thinking is a cognitive aspect that helps entrepreneurs to identify opportunities, generate ideas, creative thinking and be able to manage and control resources.

Entrepreneurial thinking is a thought that focuses on making differences from others [7], [23]-[25]. Individuals having entrepreneurial thinking are able to think at high level and in a complex way. They are persistent to learn something and have the ability to deal with complex and vague things effectively [24].

A person with entrepreneurial thinking has the ability to see and seize opportunities where other people do not see it [23]-[26]. Alsos and Kaikkonen [27] reported that the differences in the process of generating opportunities among entrepreneurs is closely related to the situation of entrepreneurs, their past experiences and their social networks.

An entrepreneur having entrepreneurial thinking also have the characteristics of creative and innovative. Individuals with creative thinking are likely to be able to see the world in a different way than others [21]. According to Mahmood et al. [28] creative and innovative individuals are those who can create new ideas and concepts and translate them to become capable product and commercial it. Moreover a person with innovative characteristics is an entrepreneur who always wants to grow and innovate or modify the existing products by improving or retrieving the quality of the product to create competitive advantage and always be in the frontline [29].

Besides having the ability to recognize and seize opportunities, being creative and innovative, individuals with entrepreneurial thinking are risk-takers and have the ability to manage vagueness. Entrepreneurs make judgments and considerations based on the risk taken [28] and able to transferred some of the risks and minimized it [29], [30]. Entrepreneurs who are entrepreneur-minded also have a high degree of handling the situation of ambiguity and uncertainty and know how to minimize it [30].

Based on the entrepreneurial thinking concept from past studies and scholars in entrepreneurship [7], [20]-[24], [31], [32], almost all of them come to the consensus that dimensions of entrepreneurial thinking include the elements of opportunity recognition, creative and innovative, risk taking and tolerance for ambiguity. As a conclusion, it can be summarized that in order to evaluate entrepreneurial thinking among individual, four aspects have to be considered, which are ability to see and seize the opportunities, creative and innovative, ability to take risk and tolerance for ambiguity. 


\section{Relationship of Entrepreneurship Education and Entrepreneurial Thinking}

Entrepreneurship education plays an important role in cultivating entrepreneurial thinking, entrepreneurial attitudes and developing entrepreneurial skills to mould a person to become entrepreneur. In this regard according to Lewis [33], the main thing required is a change in mentality as this change will facilitate the formation of entrepreneurial behavior and attitudes. However, it cannot be denied that it is not easy to develop entrepreneurial thinking in individuals. However according to Kao [34] in Hamzah et al. [35] entrepreneurship education offered in higher learning institutions is able to shape students' thinking towards an ideal entrepreneur. An entrepreneurial thinking mindset can be formed through appropriate curriculum and entrepreneurship education [14], [33], [36]. This statement is in line with De Bono [21] which states that thinking is a skill that can be improved through training, practice and through learning how to do something better.

In this regard, HLIs need to develop and create innovative entrepreneurship programs that are able to provide and educate students in developing entrepreneurial thinking. The level of creativity or intelligence is determined by genetic factors but education or early stimulation is said to be able to develop the potential of one's creativity and intelligence. Creativity is a capability that is desired by every individual and can be developed through appropriate educational programs.

Entrepreneurship education aims at expanding the potential of students towards a more creative and innovative way, teaching individuals to identify opportunities and seize opportunities that emerge in the environment, translating ideas into reality or an economic activity, while staying competitive and sensitive to changes and uncertainty [2], [15]. Through entrepreneurship education entrepreneurs and potential entrepreneurs learn to face stress, challenges and uncertainties in the environment [37]. Sexton and Bowman [38] study found that student taking entrepreneurship courses have high scores in adapting forces of changes, innovation and in ability to take risk.

Similarly, a study by Bakar et al. [39] on graduates of UUM majoring in entrepreneurship found that entrepreneurial thinking among these graduates from the aspect of opportunity recognition dimension was at high level. The finding of this study was in line with Mohamad and Ishak [40], a study of former Women in Social Enterprise (WISE) participants, whereby entrepreneurial thinking dimensions of opportunity recognition and risk taking were at high level. The WISE program is a knowledge transfer program on business skills from HLIs to micro entrepreneurs of Amanah Ikhtiar Malaysia (AIM).

Related to above factors, the research proposes the following hypotheses:

Ha1: There is a significant difference of entrepreneurial thinking among PHLIs students based on CBE course taken.

Ha2: There is a significant difference in dimension of opportunity recognition among PHLIs students based on CBE course taken.

Ha3: There is a significant difference in dimension of creativite and innovative among PHLIs students based on CBE course taken.
Ha4: There is a significant difference in dimensionof risk taking among PHLIs students based on CBE course taken.

Ha5: There is a significant difference in dimension of tolerance of ambiquity among PHLIs students based on CBE course taken.

\section{Methodology}

The population of this study consists of students from twenty PHLIs in Malaysia majoring in all fields of studies. The sample consists of 1,998 undergraduate PHLI's students who were taken randomly from twenty PHLIs in Malaysia.

The instrument of the study was adopted from Mohamad [7] consist of 29 items that is used to measure the construct of entrepreneurial thinking which have a Cronbach Alpha of 0.949. The Cronbach Alpha for dimension of opportunity recognitions ( 16 items) was 0.948 , followed by risk taking $(5$ items) with a Cronbach Alpha of 0.85 , while Cronbach Alpha for creative and innovative (4 items), and tolerance for ambiguity (4 items) have a value of 0.816 and 0.805 respectively.

To answer the research question one, descriptive analysis was applied where interpretation of the mean score in Table 1 below was used to determine the level of entrepreneurial thinking and entrepreneurial thinking dimension of PHLI students who have taken CBE.

TABLE I: MEAN SCORE INTERPRETATION

\begin{tabular}{ll}
\hline Mean score & Interpretation of Mean Score \\
\hline $1.00-2.00$ & Low \\
$2.01-3.00$ & Moderately low \\
$3.01-4.00$ & Moderately high \\
$4.01-5.00$ & High \\
\hline
\end{tabular}

Source: Mohamad [7], Othman et al. [41]

To answer research question two and research question three, a statistical inference, which is a t-test analysis, was used to test the hypothesis of the significant differences of entrepreneurial thinking and dimension of entrepreneurial thinking base on the CBE course taken among student in PHLIs.

\section{RESEARCH FINDINGS}

\section{A. The Level of Entrepreneurial Thinking and Entrepreneurial Thinking Dimensions}

Table II illustrates the findings of the level of entrepreneurial thinking and dimensions of entrepreneurial thinking of PHLIs students based on CBE course taken at the university.

The result of mean score for four dimensions of entrepreneurial thinking show only two dimensions; risk taking and opportunity recognition achieved at high level. Dimension of risk taking has the highest mean score of 4.152 and a standard deviation of 0.564 . This is followed by 
dimensions of opportunity identification with a mean score of 4.044 and a standard deviation of 0.564 . The other two dimensions which is tolerance of ambiguity and creative and innovative achieved at moderately high level.

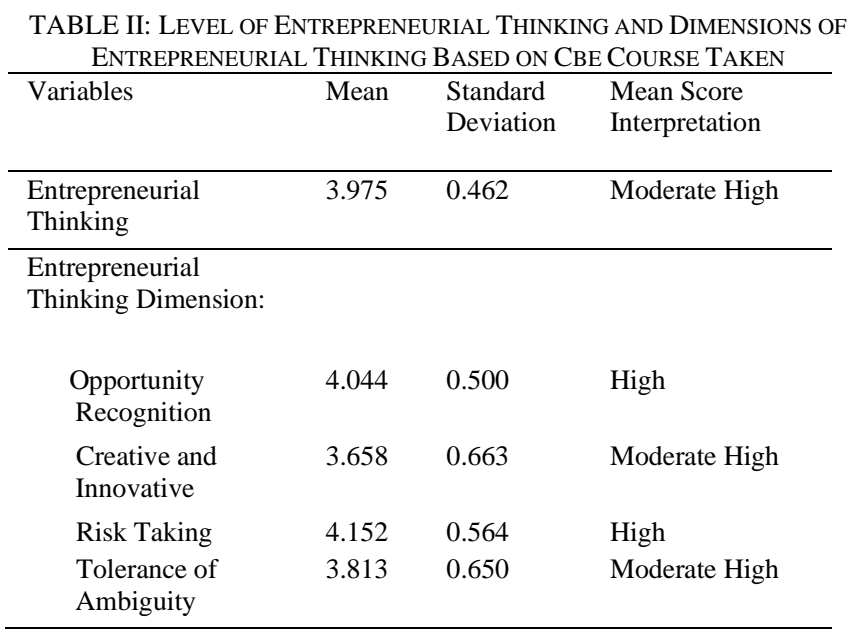

\section{B. T-test Analysis}

T-test analysis was used to answer the research question two and research question three. Follows are the result from the t-test analysis.

TABLE III: T-TEST RESULT OF ENTREPRENEURIAL THINKING AND DiMENSIONS OF ENTREPRENEURIAL THINKING BASED ON CBE COURSE

\begin{tabular}{|c|c|c|c|c|c|}
\hline Variables and Items & $\mathrm{N}$ & AKEN & $\begin{array}{l}\text { Standard } \\
\text { Deviation }\end{array}$ & $\mathrm{t}$ & Sig \\
\hline $\begin{array}{l}\text { Entrepreneurial } \\
\text { Thinking: } \\
\text { CBE course taken } \\
\text { Not taking any } \\
\text { entrepreneurship course }\end{array}$ & $\begin{array}{l}958 \\
1040\end{array}$ & $\begin{array}{l}3.975 \\
3.850\end{array}$ & $\begin{array}{l}0.462 \\
0.475\end{array}$ & 5.965 & 0.000 \\
\hline $\begin{array}{l}\text { Opportunity } \\
\text { Recognition: } \\
\text { CBE course taken } \\
\text { Not taking any } \\
\text { entrepreneurship course }\end{array}$ & $\begin{array}{l}958 \\
1040\end{array}$ & $\begin{array}{l}4.044 \\
3.898\end{array}$ & $\begin{array}{l}0.500 \\
0.501\end{array}$ & 6.553 & 0.000 \\
\hline $\begin{array}{l}\text { Creative and } \\
\text { Innovative: } \\
\text { CBE course taken } \\
\text { Not taking any } \\
\text { entrepreneurship course }\end{array}$ & $\begin{array}{l}958 \\
1040\end{array}$ & $\begin{array}{l}3.658 \\
3.593\end{array}$ & $\begin{array}{l}0.663 \\
0.655\end{array}$ & 2.201 & 0.028 \\
\hline $\begin{array}{l}\text { Risk Taking: } \\
\text { CBE course taken } \\
\text { Not taking any } \\
\text { entrepreneurship course }\end{array}$ & $\begin{array}{l}958 \\
1040\end{array}$ & $\begin{array}{l}4.152 \\
4.001\end{array}$ & $\begin{array}{l}0.564 \\
0.579\end{array}$ & 5.904 & 0.000 \\
\hline $\begin{array}{l}\text { Tolerance of } \\
\text { ambiguity: } \\
\text { CBE course taken } \\
\text { Not taking any } \\
\text { entrepreneurship course }\end{array}$ & $\begin{array}{l}958 \\
1040\end{array}$ & $\begin{array}{l}3.813 \\
3.737\end{array}$ & $\begin{array}{l}0.650 \\
0.665\end{array}$ & 2.582 & 0.010 \\
\hline
\end{tabular}

Table III illustrates the t-test results of entrepreneurial thinking and dimensions of entrepreneurial thinking, namely opportunity recognition, creative and innovative, risk taking and tolerance of ambiguity among PHLIs students based on CBE course taken at the university. As shown in the table I, entrepreneurial thinking and all dimensions of entrepreneurial thinking tested, namely opportunity recognition, creative and innovative, risk taking and tolerance of ambiguity have significant value which are all less than $0.05(p<0.05)$. These results show that there were significant differences of entrepreneurial thinking and all dimensions of entrepreneurial thinking among PHLIs students base on the CBE course taken. Among the four dimensions of entrepreneurial thinking, the two most significant differences are opportunity recognition $(t=6.553$, $p=0.000)$ and risk taking $(t=5.904, p=0.000)$

\section{DISCUSSION AND RECOMMENDATION}

The level of entrepreneurial thinking and its dimensions which is tolerance of ambiguity and creative and innovative were at moderately high level. This result demonstrates that even though entrepreneurship education plays an important role in cultivating entrepreneurial thinking, however, it cannot be denied that it is not easy to develop entrepreneurial thinking in individuals [2].

The other two dimensions of entrepreneurial thinking which are opportunity recognition and risk taking were at high level. This research result confirms with the study by Bakar et al. [39], Mohamad and Ishak [40] on opportunity recognition and parallel with Sexton and Bowman [38], Mohamad and Ishak [40] on risk taking. The findings also showed that individuals who have acquired entrepreneurial education have been trained to alert to see and seize opportunities as well as having the ability to take risk.

The t-test results showed that there were significant differences of entrepreneurial thinking and all of it dimensions among PHLIs students base on CBE course taken. This result demonstrated that students whom have taken basic entrepreneurship course have higher mean score as compare to students whom have not taken any entrepreneurship course. In this regard, the study supported the statement whereby an entrepreneurial thinking mindset can be formed through appropriate curriculum and entrepreneurship education [2], [7], [33], [36]. This finding is also in line with De Bono [21] which states that thinking is a skill that can be improved through training and learning how to do something better. Moreover, according to Kao [34] in Hamzah et al. [35] entrepreneurship education offered in higher learning institutions is able to shape students' thinking towards an ideal entrepreneur.

The results of this research also showed that there were significant differences of entrepreneurial thinking and its dimensions, namely opportunity recognition, creative and innovative, risk taking and tolerance of ambiguity, among PHLIs students base on CBE course taken. The findings justify that students whom have taken the CBE have higher mean score for opportunity recognition, creative and innovative, risk taking and tolerance of ambiguity [7], as compare to students whom have not taken any entrepreneurship course. Among the four dimensions of entrepreneurial thinking, the two dimensions having most significant differences are opportunity recognition and risk taking.

Based on this research finding, few suggestions were made. PHLIs need to develop and create innovative entrepreneurship programs that are able to provide and educate students in developing entrepreneurial thinking. This study recommended that PHLIs has to introduce more than one entrepreneurship course as a compulsory subject in order to increase the level of entrepreneurial thinking and its 
dimensions among students. McMullan et al. [42] reported that there was a high rate of new venture creation among MBA students from Canada University that have taken more than three courses related to entrepreneurship. Moreover, a study by Razak [43] on students of Bachelor of Entrepreneurship program at University Utara Malaysia (UUM) found that students attended entrepreneurship courses and entrepreneurship training under Institute of Entrepreneurship Development and Cooperative in UUM were more creative and innovative than those taken only entrepreneurship courses under the program.

Past study reported that students having high level of entrepreneurial thinking will have more tendencies to become student's enterprise on campus and graduate entrepreneur after graduation. Even though this study showed a difference in entrepreneurial thinking among students taking CBE course, the level of entrepreneurial thinking and its dimensions (creative and innovative, and tolerance of ambiguity) is still at a moderately high level.

\section{CONCLUSION}

This study accomplished the objective of identifying the level of entrepreneurial thinking and its dimensions among PHLIs students based on CBE course taken. This study found that. students who have taken a CBE course showed a higher mean of entrepreneurial thinking and by dimensions as compare to those students that have not yet taken the course. Thus, entrepreneurial thinking can be cultivated, built and developed among HLIs students through appropriate entrepreneurship education. Hence, the development of entrepreneurial thinking in all HLIs through entrepreneurship education should be implemented. By cultivating entrepreneurial thinking, it is hoped that HLIs will produce more graduates who will become a job creator. For future research, it is recommended that researchers should extend this study to focus on every field of study at HLIs. Due to a limited time, the coverage of this research is on PHLIs only and does not include a private higher learning institution. For future study researches can explore the entrepreneurial thinking among student in private HLIs and making comparison with PHLIs students.

\section{ACKNOWLEDGEMENT}

We would like to express our deepest appreciation to Ministry of Higher Education Malaysia who provided the funding for this research through the Exploratory Research Grant Scheme (ERGS).

\section{REFERENCES}

[1] H. H. Frederick and D. F. Kuratko, Entrepreneurship: Theory, Process and Practice, 2nd ed. Asia-Pacific, Australia: Cengage Learning, 2010.

[2] N. A. Buang, S. Ishak, A. Mohamad, and N. Hashim, "Cabaran membangun usahawan siswazah Malaysia," Dewan Bahasa dan Pustaka, 2018, p. 329.

[3] A. H. Ahmad, Y. Don, M. F. Sakdan, M. S. Khalid, and Y. Daud, "Kajian impak program pembangunan keusahawanan kolej komuniti," Laporan akhir projek penyelidikan Universiti Utara Malaysia, 2012

[4] M. S. Din, N. Mohamed, A. R. Salleh, H. M. M. Haneefah, Z Hussin, A. R. Chik, and A. M. A. Karim, "Pengesanan siswazah Universiti Utara Malaysia (1994-1999) Universiti Utara Malaysia, Sintok," 2002.
[5] Z. Hussin, M. S. Din, A. M. Karim, H. M. M. Hanafeah, A. R. Salleh, M. N. Mohamed, and A. R. Chik, "Graduate employment as a challenge to higher education: the case of Universiti Utara Malaysia," in Proc. International Conference on Management Education, pp. 712-719, June 28-29, 2004.

[6] Kementerian Pengajian Tinggi, Dasar Pembangunan Keusahawanan Institusi Pengajian Tinggi, 2010.

[7] A. Mohamad, "Penilaian pelaksanaan program siswaniaga Universiti Kebangsaan Malaysia,” Ph.D. dissertation, Universiti Kebangsaan Malaysia, 2014.

[8] D. C. McClelland, The Achieving Society, New York: The Free Press, 1961.

[9] D. F. Kuratko and R. M. Hodgetts, "Entrepreneurship theory process practice," 6th ed. Ohio: South-Western, Thompson Corporation, 2004.

[10] Z. A. L. Pihie, Usahawan dan Keusahawan: Satu Perspektif Pendidikan, Serdang: Universiti Putra Malaysia, 2007.

[11] A. Mohamad, S. Ishak, and N. Hashim, "Perkembangan pendidikan keusahawanan dalam institusi pendidikan di Malaysia," in Proc National Conference on Entrepreneurship and Small Business, Advancing Entrepreneurship and SMEs In the Growing Challenges of Globalization, vol. 2, Malaysia, December 9-10, 2006.

[12] A. R. Amir, S. Abdullah, and A. Mohamad, "Entrepreneurial characteristics and entrepreneurial intentions among undergraduates: A case of uitm's students," Prosiding of the 1st Seminar on Entrepreneurship and Societal Development in ASEAN (ISE-SODA 2010), pp. 68-80, 2010.

[13] Y. K. Ooi, S. Christopher, and M. Denny, "Inclination towards entrepreneurship among university students: An empirical study of Malaysian university students," International Journal of Business and Social Science, vol. 2 no. 4, pp. 206-220, 2011.

[14] N. A. Buang, Draf Pendidikan Keusahawanan, 2006.

[15] P. M. Yap, "Kesediaan guru-guru perdagangan terhadap pengajaran subjek pengajian keusahawanan," M.S. thesis, Universiti Kebangsaan Malaysia, 2002.

[16] J. Pyysiainen, A. Anderson, G. McElwee, and K. Vesala, "Developing the entrepreneurial skills of farmers: some myths explored," International Journal of Entrepreneurial Behaviour \& Research, vol. 12 no.1, pp. 21-39, 2006.

[17] Kementerian Pengajian Tinggi Malaysia, Kod Amalan Kualiti Institusi Pengajian Awam Malaysia, 2005.

[18] S. C. Hassan, A. Mohamad, and A.M. Noor, "Potensi kolej komuniti sebagai wadah pembentukan 'Majikan' Lestari," National Proceedings of Economics, vol. 8, UKM, Johor Bahru, 2013.

[19] B. Din, A.R. Anuar, and M. Usman, "The entrepreneurship education program in Malaysian public university," The European Proceedings of Social and Behavioral Sciences, International Soft Science Conference, p. 449, 2016.

[20] J. A. Timmons and S. Spinelli, New Venture Creation Entrepreneurs for the 21st Century, 6th ed. New York: McGraw Hill/Irwin, 2004.

[21] E. De Bono, Edward De Bono Thinking Course: Powerful Tools to Transform Your Thinking, England: BBC Active, 2006.

[22] N. Hashim, "Kesediaan keusahawanan pelajar dan persekitaran dalaman institusi pengajian tinggi awam Malaysia dalam melaksanakan pendidikan keusahawanan," Ph.D. dissertation, Universiti Kebangsaan Malaysia, 2009.

[23] R. W. Clouse, T. Goodin, M. Davey, and J. Burgoyne "Entrepreneurs in action: an integrated approach to problem solving via the internet," 2003.

[24] L. J. Higdon. (2005). Liberal education and the entrepreneurial mindset a twenty-first-century approach. [Online]. Available: http://www.aacu.org/liberaleducation/le-wi05/lewi05perspective2.cfm

[25] D. F. Kuratko, Introduction to Entrepreneurship, 8th ed. Australia: South-Western Cengage Learning, 2009.

[26] H. K. S. Alhnaity, "The influence of entrepreneurial thinking, attitute, networks and government intervention on the small business owners' performance in Jordan," Ph.D. dissertation, Universiti Utara Malaysia, 2018.

[27] G.A. Alsos, and V. Kaikkonen, "Opportunity recognition and prior knowledge: A study of experienced entrepreneurs," Nordic Conference on Small Business Research, vol. 13, 2004.

[28] R. Mahmood, L. J. A. Bakar, M. Y. M. Jani, M. S. Bakar, N Deraman, N. Zakaria, S. Abdullah, R. M. Saad, and A. N. Mustapa, Prinsip-Prinsip Asas Keusahawanan, Kuala Lumpur: Thomson, 2007.

[29] M. S. Din, C. H. Hoe, N. Hashim, Y. K. Ooi, S. Ahmad, H. Bakar, N. Deraman, R. Mahmood, A. Mohamad, L. J. A. Bakar and M. N. M. Hussain, Asas Keusahawanan, Australia: Thomson, 2005.

[30] N. Deraman, A. Mohamad, H. Bakar, N. Hashim, and Y. K. Ooi, Keusahawanan: Teori dan Praktis, 2nd ed. Shah Alam: McGrawHill (M) Sdn. Bhd., 2010. 
[31] C. A. Mad and M. A. M. Idris, "Impak liberalisasi dan globalisasi kepada Usahawan Malaysia," Kertas kerja Seminar Globalisasi dan Usahawan Wanita: Kepintaran, Emosi dan Integriti. Sintok, May 29$31,2002$.

[32] H. Hussin, "Cabaran dan Hala Tuju Usahawan Wanita dalam Era Globalisasi," Kertas kerja Seminar Globalisasi dan Usahawan Wanita: Kepintaran, Emosi dan Integriti. Sintok, May 29-31, 2002.

[33] K. Lewis. (2002). An Enterprising Future: Evaluating the Young Enterprise Scheme. Enterprise New Zealand Trust. [Online]. Available:

http://www..smecentre.massey.ac.nz/research/YES_evaluation_final_ Report.pdf

[34] J. J. Kao, The Entrepreneur, Englewood Cliffs: Prentice Hall, 1995.

[35] M. R. Hamzah, K. A. K. Daud, N. Ismail, N. Ahmad, and N. Nordin, "Tahap pengetahuan dan minat pelajar Universiti Malaysia perlis terhadap bidang keusahawanan: Satu tinjauan ke arah pembentukan teknousahawan Universiti Malaysia Perlis," International Proceedings of Entrepreneurship Development, 2009.

[36] L. Collins, P. D. Hannon, and A. Smith, "Enacting entrepreneurial intent: The gap between students needs and higher education capabilities," Education + Training, vol. 46, no. 8/9, pp. 454-463, 2004.

[37] U. Hytti, and C. O'Gorman, "What is enterprise education? An analysis of the objectives and methods of enterprise education programmes in four European countries," Education + Training, vol. 46, no. 1, pp. 11-23, 2004.

[38] D. L. Sexton, and N. B. Bowman, "Determining entrepreneurial potential of students," Academy of Management Proceeding, pp. 408412, 1983.

[39] H. Bakar, A. Mohamad, N. Hashim, Y. K. Ooi, and S. Abdullah, "Entrepreneurial thinking among entrepreneurship students: The case of Universiti Utara Malaysia," Kertas kerja LEADS Universiti Utara Malaysia, 2013.

[40] A. Mohamad and A. K. Ishak, "Menerokai tahap pemupukan pemikiran keusahawanan pelajar di institusi pengajian tinggi awam di Malaysia: Kes program wise," Prosiding Seminar Hasil Penyelidikan Sektor Pengajian Tinggi Awam, pp.1096-1108, 2013.

[41] N. Othman, H. Harun, F. Karim, Z. A. L. Pihie and N. Buang, "Pembentukan indeks tingkah laku keusahawanan golongan remaja sekolah Malaysia: laporan akhir projek IRPA," Universiti Kebangsaan Malaysia 07-02-02-0036 EA 276, 2006.

[42] W. E. McMullan, W. A. Long, and A. Wilson, "MBA concentration on entrepreneurship," Journal of Small Business and Enterpreneurship, vol. 3, no. 1, pp. 18-22, 1985.

[43] R. I. A. Razak, "Kreativiti dan inovasi dalam kalangan pelajar sarjana ijazah muda Universiti Utara Malaysia," Bachelor'S Degree Dissertation, Universiti Utara Malaysia, 2010.

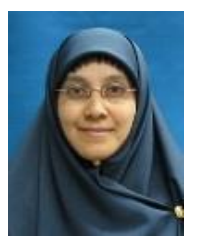

Armanurah Mohamad was born in Perlis, Malaysia in 1961. She received her bachelor in business management (finance) from California State University, Fresno in 1985, and her MBA from the University of Wisconsin, USA in 1987. In 1991 she received her diploma of education. she earned her phd in business and entrepreneurship education from Universiti Kebangsaan Malaysia in 2014. Before joining UUM, she was a secondary teacher for 10 years. She joined UUM as a lecturer in 2001. She is currently a senior lecturer at School of Business Managament, UUM. She taught various entrepreneurship courses and supervised $\mathrm{PhD}$ and Master students under various area of entrepreneurship. Dr Armanurah has conducted and involved in many entrepreneurial training, consultation and mentoring to entepreneurs and potential entrepreneurs.

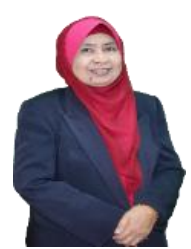

Syahrina Abdullah was born in Penang, Malaysia in 1976. She received her bachelor in human resource management (hons) in 1999. In 2003, she earned her MSc. entrepreneurship degree from the University of Glasgow, United Kingdom. Before joining UUM, she was Supervisor (Quality Assurance). for 2 years and Human Resources Assistant for 1 year. She joined UUM in 2001 and currently as a lecturer in entrepreneurship field. Mrs. Syahrina has conducted and involved in many entrepreneurial training, and consultation to entepreneurs and potential entrepreneurs.

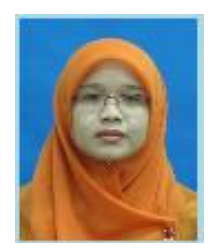

Awanis Ku Ishak was born in Penang, Malaysia in 1969. She earned a diploma in accountancy from Universiti Teknologi MARA in 1990. In 1995, she earned a degree in marketing from the University of Southern Queensland. She received her MBA in 2006 and her $\mathrm{PhD}$ (organisational behavior) from UUM in 2012. Before joining UUM, she was a project manager for 2 years and business manager for 7 years. She joined UUM as a lecturer in 2007. She has taught various courses at undergraduate and postgraduate level in research methodology, organisational behavior, management as well as marketing. She is currently supervising PhD/DBA, Master and undergraduate students in research under those area. Dr Awanis has conducted several research methodology workshops and training.

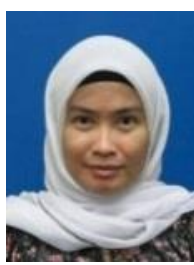

Norashidah Hashim was born in Pahang, Malaysia in 1966. She received her bachelor of economics from La Trobe University, Victoria, Australia in 1989. She earned her diploma of education from International Islamic University of Malaysia in 1991 and her master of education in 2000 from Universiti Teknologi Malaysia. She received her $\mathrm{PhD}$ (business and entrepreneurship education) from Universiti Kebangsaan Malaysia in 2009. Before joining UUM, she was a secondary teacher for 10 years. She joined UUM as a lecturer in 2001. She is currently attached to School of Business Managament, UUM as an assosiate profesor and has taught various entrepreneurship courses. She is currently supervising $\mathrm{PhD}$ and Master students in area of entrepreneurship. Dr Norashidah has conducted and involved in many entrepreneurial training, consultation and mentoring to entepreneurs and potential entrepreneurs. 